\title{
Hasil skrining berdasarkan metode MNA (mini nutritional assestment) tidak berpengaruh terhadap lama rawat inap dan status pulang pasien lanjut usia di RSUP Dr. Sardjito Yogyakarta
}

Screening result based on mini nutritional assessment (MNA) method had no impact to the length of stay and discharge status of the elderly patient at Dr. Sardjito Hospital Yogyakarta

Wahyu Hardi Prasetyo', I Dewa Putu Pramantara², R. Dwi Budiningsari ${ }^{3}$

\begin{abstract}
Background: The number of elderly people (over 60 years old) is growing rapidly in this $21^{\text {th }}$ century, reaching as many as 425 millions $( \pm 6.8 \%)$ worldwide in 2000 . This figure is estimated almost twice in 2025. In Indonesia, percentage the elderly people in 1995 was as much as $7.5 \%$. In line with the increasing of live expectancy of the number of the elderly will grow bigger. This is related to greater need of health service for the eldery. In older people, nutrition problem is closely associated with disease. One factor that causes nutrition problem in the elderly is the increase of morbidity. Increased risk for disease and nutrition problem in the elderly require early identification of risk for malnutrition in the elderly. Routine assessment of preliminary nutritional status of patients being hospitalized is essential in order to get an overview of nutritional status patients at a time, detect high risk patients and help to identify nutrition treatment specifically for each patient so that appropriate nutrition support can be given to improve nutrition status of patient.

Objectives: To identify the impact of early screening nutrition result based on MNA method to the length of stay and discharge status of elderly patients at inpatient ward of internal medicine and neurology of Dr Sardjito Hospital Yogyakarta.

Methods: The study was observational that used prospective cohort design and was undertaken at inpatient ward of internal in medicine and neurologyod Dr. Sardjito Hospital, Yogyakarta on August-November 2009. Data were collected by the researcher with the help of an enumerator, i.e. nutritionsist at inpatient ward. Results: The result of study showed that impact of screening result during initial hospitalization to length of stay of eldery patients based on MNA method was RR 1.63. This indicated that malnourished patients were at risk for being hospitalized $\geq 7$ days 1.63 times longer than those not malnourished. Impact of result screening during initial hospitalization to discharge status of eldery patients based on MNA method was $R R$ 1.29. This indicated that malnourished patient were at risk for uncovered discharged as much as 1.29 greater than those not malnourhized.

Conclusions: There was no impact of screening result in admission to length of stay. There was impact of nutritional status to length of discharged status.
\end{abstract}

KEYWORDS: discharge home, length of stay, nutritional status in initial admission

\begin{abstract}
ABSTRAK
Latar belakang: Pertumbuhan penduduk lanjut usia (umur $\geq 60$ tahun) meningkat secara cepat pada abad 21 ini, yang pada 2000 di seluruh dunia telah mencapai 425 juta jiwa $( \pm 6,8 \%)$. Jumlah ini diperkirakan akan mengalami peningkatan hampir dua kali lipat pada 2025. Di Indonesia, persentase lanjut usia pada 1995 mencapai 7,5\%. Dengan meningkatnya angka harapan hidup, jumlah lanjut usia pun akan bertambah
\end{abstract}

\footnotetext{
'Ulin Hospital, JI. A. Yani No 43, Banjarmasin, Kalimantan Selatan

2 Bagian Penyakit Dalam RSUP Dr. Sardjito, Jl. Kesehatan, Yogyakarta

${ }^{3}$ Minat Gizi dan Kesehatan Fakultas Kedokteran UGM, Jl. Farmako, Sekip Utara, Yogyakarta 55281
} 
banyak. Hal ini terkait dengan perlunya peningkatan pelayanan kesehatan lanjut usia. Pada lanjut usia, masalah gizi erat kaitannya dengan penyakit. Salah satu faktor yang menyebabkan lanjut usia menjadi rawan gizi yaitu peningkatan morbiditas penyakit. Dengan meningkatnya risiko penyakit dan disertai gangguan nutrisi pada lanjut usia, perlu dilakukan identifikasi risiko malnutrisi pada lanjut usia sedini mungkin. Penilaian status gizi awal pasien masuk rumah sakit sangat penting dilakukan secara rutin karena dapat menggambarkan status gizi pasien saat itu, mendeteksi pasien-pasien yang berisiko tinggi, dan membantu mengidentifikasi perawatan gizi secara spesifik pada masing-masing pasien sehingga dukungan nutrisi yang tepat dapat diterapkan untuk meningkatan status gizi pasien.

Tujuan: Untuk mengetahui pengaruh hasil skrining awal berdasarkan metode MNA (mini nutritional assessment) terhadap lama rawat inap dan status pulang pasien lanjut pada ruang rawat inap penyakit dalam dan saraf di RSUP Dr. Sardjito Yogyakarta

Metode: Jenis penelitian ini adalah penelitian observasional dengan menggunakan rancangan kohort prospektif. Penelitian ini dilakukan di ruang rawat inap penyakit dalam dan saraf pada pasien lanjut usia di Rumah Sakit Umum Pusat Dr. Sardjito Yogyakarta. Penelitian dilaksanakan pada bulan AgustusNovember 2009. Pengumpulan data dilakukan oleh peneliti dengan bantuan enumerator yaitu ahli gizi yang bertugas di ruang rawat inap.

Hasil: Berdasarkan hasil skrining dengan metode MNA pada pasien lanjut usia terhadap lama rawat inap, maka diketahui bahwa nilai $R R=1,63$. Hal ini menunjukkan bahwa pasien yang terpapar (malnutrisi) berisiko dirawat selama $\geq 7$ hari adalah 1,63 kali lebih besar daripada pasien yang tidak terpapar (tidak malnutrisi). Berdasarkan hasil regresi logistik tidak ada pengaruh antara hasil skrining dengan lama rawat inap. Ada pengaruh secara statistik antara usia, jenis penyakit dan kelas perawatan terhadap lama rawat inap. Berdasarkan hasil regresi logistik, jenis penyakit memiliki pengaruh yang paling dominan dengan nilai $R R$ 3,88 terhadap lama rawat inap. Berdasarkan hasil skrining awal masuk rumah sakit terhadap status pulang pasien lanjut usia berdasarkan metode $M N A$, maka diketahui nilai $R R=1,29$. Hal ini menunjukkan bahwa pasien yang terpapar (malnutrisi) berisiko keluar dalam keadaan tidak sembuh sebesar 1,29 kali lebih besar daripada pasien yang tidak terpapar (tidak malnutrisi). Berdasarkan hasil uji regresi logistik ada pengaruh antara hasil skrining dengan status pulang dengan nilai OR 9,21. Demikian pula ada pengaruh antara usia dan jenis kelamin dengan status pulang $(p<0,05)$.

Kesimpulan: Tidak ada pengaruh antara hasil skrining dengan lama rawat inap. Ada pengaruh antara usia, jenis penyakit dan kelas perawatan terhadap lama rawat inap. Ada pengaruh antara hasil skrining dengan status pulang.

KATA KUNCl: skrining, lama rawat inap, status pulang pasien

\section{PENDAHULUAN}

Saat ini angka kesakitan akibat penyakit degeneratif meningkat jumlahnya di samping masih adanya kasus penyakit infeksi dan kekurangan gizi (1). Beberapa penelitian menunjukkan bahwa malnutrisi kalori, protein, dan mikronutrien sering terjadi yang ditandai timbulnya penyakit degeneratif, salah satunya akibat asupan makan yang tidak benar (2).

Asupan gizi yang tidak cukup akan menyebabkan penurunan status gizi atau bahkan malnutrisi selama pasien dirawat inap di rumah sakit. Pada pasien lanjut usia risiko tidak cukupnya asupan gizi dinilai lebih besar, sehingga berisiko lebih besar pula untuk mengalami malnutrisi.
Besarnya prevalensi malnutrisi pasien telah banyak ditemukan sejak tahun 1970-an. Walaupun sudah banyak dilakukan berbagai upaya perawatan gizi pasien rawat inap dari tahun ke tahun, ternyata pada tahun 2000-an besarnya prevalensi malnutrisi ini tidak banyak berubah yaitu berkisar $20-60 \%(3,4)$. Suatu studi di Swedia mendapatkan 29\% lanjut usia mengalami malnutrisi ketika awal masuk rumah sakit. Studi lain mendapatkan sekitar $60 \%$ lanjut usia yang dirawat di rumah sakit mengalami kekurangan energi dan protein pada saat masuk rumah sakit atau mengalami malnutrisi ketika dirawat sampai sebelum keluar dari rumah sakit (5).

Pada lanjut usia, terjadinya malnutrisi turut berperan terhadap penurunan progresif status 
kesehatan lanjut usia sehingga terjadi peningkatan risiko terhadap penyakit. Penurunan yang progresif status kesehatan akan menurunkan kualitas hidup, menimbulkan kebutuhan akan perawatan diri serta kemungkinan terjadinya kematian sebelum waktunya (2). Pasien geriatri adalah pasien yang berusia di atas 60 tahun, mempunyai lebih dari 1 (satu) macam penyakit, dengan penurunan cadangan faali, disertai gangguan fungsi dan nutrisi disertai problem sosial dan atau psikologi (6). Untuk mencegah terjadinya malnutrisi, hendaknya selalu dilakukan skrining pada pasien, dimulai dengan anamnesis, pemeriksaan fisik, antropometri, dan pemeriksaan biokimia. Pemeriksaan awal dapat dengan cara skrining dan dapat dilakukan oleh semua petugas kesehatan (7).

Penilaian status gizi awal pasien masuk rumah sakit sangat penting dilakukan secara rutin karena dapat menggambarkan status gizi pasien saat itu, mendeteksi pasien-pasien yang berisiko tinggi malnutrisi, dan membantu mengidentifikasi perawatan gizi secara spesifik pada masing-masing pasien, sehingga dukungan nutrisi yang tepat dapat diterapkan untuk meningkatan status gizi pasien (8).

Tujuan penilaian status gizi pasien di rumah sakit adalah untuk menentukan status gizi pasien secara akurat, menentukan hubungan dengan malnutrisi secara klinis, dan memonitor perubahan status gizi selama mendapatkan terapi gizi (9). Terapi gizi yang tepat akan meningkatkan status gizi secara klinis dan biokimia, sehingga pasien mempunyai ketahanan tubuh yang baik dan risiko komplikasi yang rendah.

Mini nutritional assessment (MNA) merupakan instrumen terpilih karena cukup sederhana, lengkap dalam menilai faktor-faktor yang mungkin berperan pada status nutrisi, dan validitasnya sudah banyak diuji oleh berbagai studi di berbagai negara dan pada berbagai kondisi. Penilaian nutrisi mini (MNA) merupakan alat spesifik yang didisain untuk tujuan mengidentifikasi risiko malnutrisi pada lanjut usia sedini mungkin. MNA dapat digunakan secara berkala untuk lingkup masyarakat maupun di rumah sakit (10).

Pada lanjut usia, diagnosis malnutrisi dapat dilakukan dengan: anamnesis diet, pemeriksaan fisik, laboratorium, status fungsional, status mental dan fungsi sosial. Pada saat ini banyak dikembangkan berbagai instrumen untuk menilai status nutrisi lansia, di antaranya nutrition screening initiative (NSI), MNA, Sadness, cholesterol, albumin, loss of weight, eat dan shopping (SCALES), dan lain-lain, yang dapat dipakai sesuai kebutuhan. MNAmerupakan sebuah daftar cek berisi pertanyaan yang dibagi dalam: area penilaian antropometri, penilaian global, penilaian dietetik dan penilaian subjektif (11).

Tujuan penelitian ini adalah untuk mengetahui pengaruh hasil skrining awal berdasarkan metode MNA terhadap lama rawat inap dan status pulang pasien lanjut pada ruang rawat inap penyakit dalam dan saraf di RSUP Dr. Sardjito.

\section{BAHAN DAN METODE}

Jenis penelitian ini adalah penelitian observasional dengan menggunakan rancangan kohort prospektif. Penelitian dilaksanakan pada bulan Agustus hingga November 2009. Penelitian menggunakan teknik purposive sampling. Subjek penelitian berjumlah 77 pasien. Kriteria inklusi yaitu: bersedia menjadi subjek penelitian dibuktikan dengan mengisi infomed consent, berusia $\geq 60$ tahun, dapat berkomunikasi, pasien dalam keadaan sadar, dapat dilakukan pengukuran antropometri (BB (berat badan), TB (tinggi badan), LLA (lingkar lengan atas), dirawat di ruang rawat inap penyakit dalam kelas I, II, III. Kriteria eksklusi adalah pulang atas permintaan sendiri.

Variabel independen adalah hasil skrining (berdasarkan MNA). Variabel dependen adalah lama rawat inap dan status pulang pasien. Variabel terkendali adalah karakteristik pasien (umur, jenis kelamin, pendidikan, pekerjaan), jenis penyakit, kelas perawatan, ruang perawatan, riwayat hospitality.

Proses skrining dilakukan dengan wawancara menggunakan form MNA diambil saat pasien masuk rumah sakit ( $<24$ jam) dengan kategori normal-tidak berisiko (poin $\geq 12$ ) dan berisiko malnutrisi (poin $\leq 11$ ). Data lama rawat inap dan status pulang diperoleh dari data rekam medis. Data penelitian status gizi diperoleh melalui pengukuran antropometri dengan timbangan berat badan dengan ketelitian $0,5 \mathrm{~kg}$, alat 
pengukur tinggi lutut dengan ketelitian $0,1 \mathrm{~cm}$, pita LLA yang terbuat dari fiberglass dengan ketelitian $0,1 \mathrm{~cm}$ (semua alat telah dikalibrasi sebelumnya).

Analisis bivariat menggunakan chi-square dan multivariat menggunakan regresi logistik.

\section{HASIL}

Pasien di ruang rawat penyakit dalam dan saraf awalnya berjumlah 83 subjek, tetapi ada yang pulang atas permintaan sendiri berjumlah 6 orang, sehingga jumlah subjek menjadi 77 orang.

Berdasar Tabel 1 diketahui bahwa subjek berisiko malnutrisi berjumlah 41 subjek $(53,2 \%)$, sedangkan tidak berisiko malnutrisi berjumlah 36 subjek (46,8\%). Berdasarkan kelompok usia, subjek yang berusia 71 tahun ke atas berjumlah 48 subjek $(62,3 \%)$. Berdasarkan jenis penyakit, umumnya subjek memiliki jenis penyakit non-infeksi berjumlah 41 subjek $(53,2 \%)$. Berdasarkan riwayat hospitalisasi, subjek dalam penelitian ini adalah subjek yang bukan memiliki riwayat hospitalisasi. Usia dan jenis penyakit memiliki hubungan dengan keterpaparan seseorang terhadap malnutrisi $(p<0,05)$.

Karakteristik berdasarkan lama rawat inap dapat dilihat pada Tabel 2. Subjek yang dirawat lebih atau sama dengan 7 hari berjumlah 43 subjek $(55,8 \%)$ sedangkan kurang dari 7 hari berjumlah 34 subjek $(44,2 \%)$. Subjek yang berusia lebih atau sama dengan 71 tahun ke atas sebagian besar di rawat inap kurang dari 7 hari $(56,3 \%)$, sebaliknya subjek yang berusia 60-70 tahun sebagian besar dirawat inap lebih dari 7 hari $(75,9 \%)$. Subjek yang berada di kelas 2 dan 3 sebagian besar dirawat inap lebih dari 7 hari $(33,3 \%)$, sedangkan subjek yang berada di kelas 1 sebagian besar berada di rawat inap kurang dari 7 hari $(66,7 \%)$. Subjek yang memiliki penyakit infeksi sebagian kecil dirawat inap lebih dari 7 hari $(41,7 \%)$ sedangkan subjek yang memiliki penyakit tidak infeksi sebagian besar dirawat inap lebih dari 7 hari $(68,3 \%)$.

Subjek dengan pendidikan SD dan SMP sebagian besar dirawat inap lebih dari 7 hari $(60,5 \%)$ sedangkan subjek dengan latar pendidikan SMA sebagian yang sama dirawat inap lebih dari 7 hari $(50 \%)$. Subjek di bangsal saraf dirawat inap lebih dari 7 hari $(51,6 \%)$ sedangkan pasien di bangsal penyakit dalam sebagian besar dirawat inap lebih dari 7 hari $(58,7 \%)$. Berdasarkan hasil uji chi-square, diketahui bahwa seluruh karakteristik terdistribusi seimbang antara lama rawat inap panjang (lebih atau sama dengan 7 hari) dan pendek (kurang dari 7 hari), kecuali pada kelas perawatan dan jenis penyakit $(p<0,05)$. Oleh karena itu, kedua variabel ini akan diikutsertakan pada uji multivariat. Demikian pula pada variabel usia karena menunjukkan nilai $p$ kurang dari 0,25.

Karakteristik subjek berdasarkan status pulang dapat diketahui dari Tabel 3. Subjek yang sembuh berjumlah 52 subjek $(67,5 \%)$ sedangkan yang tidak sembuh 25 subjek (32,5\%). Subjek yang usia lebih atau sama 71 tahun ke atas sebagian kecil tidak sembuh $(62,5 \%)$, sebaliknya subjek yang berusia 60-70 tahun sebagian besar tidak sembuh $(75,9 \%)$. Setelah dianalisis secara statistik, didapatkan nilai $p=0,031$, artinya ada perbedaan signifikan antara usia dengan status pulang. Subjek yang berada di kelas 2 dan 3 sebagian besar keluar dalam keadaan

Tabel 1. Karakteristik subjek berdasarkan kelompok berisiko dan tidak berisiko

\begin{tabular}{|c|c|c|c|c|c|c|c|c|}
\hline \multirow[t]{2}{*}{ Karakteristik } & \multicolumn{2}{|c|}{$\begin{array}{c}\text { Kelompok } \\
\text { berisiko }\end{array}$} & \multicolumn{2}{|c|}{$\begin{array}{l}\text { Kelompok tidak } \\
\text { berisiko }\end{array}$} & \multirow[t]{2}{*}{$\mathbf{N}$} & \multirow[t]{2}{*}{$\%$} & \multirow[t]{2}{*}{$\chi^{2}$} & \multirow[t]{2}{*}{$\mathbf{p}$} \\
\hline & $\mathbf{n}$ & $\%$ & $\mathbf{n}$ & $\%$ & & & & \\
\hline \multicolumn{9}{|l|}{ Usia } \\
\hline 71 tahun ke atas & 19 & 39,6 & 29 & 60,4 & 48 & 62,3 & \multirow{2}{*}{9,55} & \multirow{2}{*}{$0,002^{*}$} \\
\hline $60-70$ tahun & 22 & 75,9 & 7 & 24,1 & 29 & 37,7 & & \\
\hline \multicolumn{9}{|l|}{ Jenis penyakit } \\
\hline Infeksi & 14 & 38,9 & 22 & 61,1 & 36 & 46,8 & \multirow{2}{*}{5,59} & \multirow{2}{*}{$0,023^{*}$} \\
\hline Noninfeksi & 27 & 65,9 & 14 & 34,1 & 41 & 53,2 & & \\
\hline \multicolumn{9}{|l|}{ Riwayat hospitalisasi } \\
\hline Ya & 16 & 47,1 & 18 & 52,9 & 34 & 40,3 & \multirow{2}{*}{0,93} & \multirow{2}{*}{0,36} \\
\hline Tidak & 25 & 58,1 & 18 & 41,9 & 43 & 59,7 & & \\
\hline
\end{tabular}

\footnotetext{
* Signifikan $(p<0,05)$
} 
Tabel 2. Karakteristik berdasarkan lama rawat inap

\begin{tabular}{|c|c|c|c|c|}
\hline \multirow[b]{2}{*}{ Karakteristik } & \multicolumn{2}{|c|}{ Lama rawat inap } & \multirow[b]{2}{*}{$\chi^{2}$} & \multirow[b]{2}{*}{$\mathbf{p}$} \\
\hline & $\begin{array}{c}\geq 7 \text { hari } \\
\text { n (\%) }\end{array}$ & $\begin{array}{c}<7 \text { hari } \\
\text { n (\%) }\end{array}$ & & \\
\hline \multicolumn{5}{|l|}{ Usia } \\
\hline$\geq 71$ tahun & $21(43,8)$ & $27(56,3)$ & 7,56 & 0,09 \\
\hline $60-70$ tahun & $22(75,9)$ & $7(24,1)$ & & \\
\hline \multicolumn{5}{|l|}{ Jenis kelamin } \\
\hline Perempuan & $15(50)$ & $15(50)$ & 0,68 & 0,48 \\
\hline Laki-laki & $28(59,6)$ & $19(40,4)$ & & \\
\hline \multicolumn{5}{|l|}{ Pendidikan } \\
\hline SD dan SMP & $26(60,5)$ & $17(39,5)$ & 0,84 & 0,48 \\
\hline SMA & $17(50)$ & $17(50)$ & & \\
\hline \multicolumn{5}{|l|}{ Kelas perawatan } \\
\hline Kelas 2 dan 3 & $33(70,2)$ & $14(29,8)$ & 10,10 & 0,00 \\
\hline Kelas 1 & $10(33,3)$ & $20(66,7)$ & & \\
\hline \multicolumn{5}{|l|}{ Jenis penyakit } \\
\hline Infeksi & $15(41,7)$ & $21(58,3)$ & 5,51 & 0,02 \\
\hline Tidak infeksi & $28(68,3)$ & $13(31,7)$ & & \\
\hline \multicolumn{5}{|l|}{ Ruang perawatan } \\
\hline Saraf & $16(51,6)$ & $15(48,4)$ & 0,37 & 0,64 \\
\hline Penyakit dalam & $27(58,7)$ & $19(41,3)$ & & \\
\hline \multicolumn{5}{|l|}{ Riwayat hospitalisasi } \\
\hline $\mathrm{Ya}$ & $17(50)$ & $17(50)$ & 0,84 & 0,48 \\
\hline Tidak & $26(60,5)$ & $17(39,5)$ & & \\
\hline
\end{tabular}

Tabel 3. Karakteristik berdasarkan status pulang

\begin{tabular}{|c|c|c|c|c|}
\hline \multirow{2}{*}{ Karakteristik } & \multicolumn{2}{|c|}{ Status pulang } & \multirow{2}{*}{$\chi^{2}$} & \multirow{2}{*}{$\mathbf{p}$} \\
\hline & Tidak sembuh & Sembuh & & \\
\hline \multicolumn{5}{|l|}{ Usia } \\
\hline$\geq 71$ tahun & $30(62,5)$ & $18(37,5)$ & 1,42 & 0,31 \\
\hline $60-70$ tahun & $22(75,9)$ & $7(24,1)$ & & \\
\hline \multicolumn{5}{|l|}{ Jenis kelamin } \\
\hline Perempuan & $28(93,3)$ & $2(6,7)$ & 14,92 & 0,00 \\
\hline Laki-laki & $24(51,1)$ & $23(48,9)$ & & \\
\hline \multicolumn{5}{|l|}{ Pendidikan } \\
\hline SD dan SMP & $27(62,8)$ & $16(37,2)$ & 0,99 & 0,34 \\
\hline SMA & $25(73,5)$ & $9(26,5)$ & & \\
\hline \multicolumn{5}{|l|}{ Kelas perawatan } \\
\hline Kelas 2 dan 3 & $31(66)$ & $16(34)$ & 0,13 & 0,80 \\
\hline Kelas 1 & $21(70)$ & $9(30)$ & & \\
\hline \multicolumn{5}{|l|}{ Jenis penyakit } \\
\hline Infeksi & $23(63,9)$ & $13(36,1)$ & 0,40 & 0,62 \\
\hline Tidak infeksi & $29(70,7)$ & $12(29,3)$ & & \\
\hline \multicolumn{5}{|l|}{ Ruang perawatan } \\
\hline Saraf & $20(64,5)$ & $11(35,5)$ & 0,21 & 0,80 \\
\hline Penyakit dalam & $27(69,6)$ & $19(30,4)$ & & \\
\hline \multicolumn{5}{|l|}{ Riwayat hospitalisasi } \\
\hline $\mathrm{Ya}$ & $20(58,8)$ & $14(41,2)$ & 2,10 & 0,22 \\
\hline Tidak & $32(74,4)$ & $11(25,6)$ & & \\
\hline
\end{tabular}

tidak sembuh 31 subjek (66\%) sedangkan subjek yang berada di kelas 1 sebagian besar tidak sembuh 21 subjek (70\%).
Tabel 4 menunjukkan hasil uji chi-square pengaruh antara hasil skrining dengan lama rawat inap. Analisis bivariat menunjukkan bahwa dari 
41 responden yang berisiko malnutrisi, 28 subjek $(68,3 \%)$ dirawat lebih atau sama dengan 7 hari sedangkan subjek yang dirawat kurang dari 7 hari berjumlah 13 subjek (31,7\%). Dari 36 subjek tidak berisiko 15 subjek $(41,7 \%)$ dirawat lebih atau sama dengan 7 hari, sedangkan subjek yang dirawat kurang dari 7 hari berjumlah 21 subjek $(58,3 \%)$.

Besarnya risiko dapat dilihat pada nilai RR sebesar 1,63. Hal ini menunjukkan bahwa pasien yang berisiko malnutrisi, berisiko dirawat lebih atau sama dengan 7 hari adalah 1,63 kali lebih besar daripada subjek yang tidak berisiko malnutrisi. Berdasarkan hasil uji chi-square diketahui ada perbedaan signifikan antara hasil skrining dengan lama rawat inap $(p<0,05)$

Berdasarkan Tabel 5 diketahui bahwa analisis bivariat menunjukkan bahwa dari 41 subjek yang berisiko malnutrisi, 31 subjek $(75,6 \%)$ tidak sembuh sedangkan subjek yang sembuh 10 subjek $(24,4 \%)$. Dari 36 subjek tidak berisiko malnutrisi, 21 subjek $(58,3 \%)$ tidak sembuh sedangkan subjek yang sembuh berjumlah 15 subjek $(41,7 \%)$. Besarnya risiko dapat dilihat pada nilai $R R$, sebesar 1,29. Hal ini menunjukkan bahwa subjek yang berisiko malnutrisi memiliki risiko tidak sembuh 1,29 kali lebih besar daripada subjek yang tidak berisiko malnutrisi.
Berdasarkan hasil regresi logistik pada Tabel 6 diketahui tidak ada pengaruh antara hasil skrining dengan lama rawat inap. Ada pengaruh secara statistik antara usia, jenis penyakit, dan kelas perawatan terhadap lama rawat inap. Berdasarkan hasil regresi logistik, jenis penyakit memiliki pengaruh yang paling dominan dengan nilai $R R$ 2,63 terhadap lama rawat inap.

Sementara itu, hasil uji regresi logistik multivariat berdasarkan status pulang menyertakan hasil skrining, jenis kelamin dan riwayat hospitalisasi (Tabel 7). Berdasarkan hasil uji regresi logistik, ada pengaruh antara hasil skrining dengan status pulang dengan nilai $R R$ 9,21. Demikian pula ada pengaruh antara usia dan jenis kelamin dengan status pulang $(p<0,05)$. Sementara itu tidak ada pengaruh antara riwayat hospitalisasi dengan status pulang. Hasil skrining sebagai faktor yang paling dominan terhadap status pulang dengan nilai $\operatorname{RR~9,21.~}$

\section{BAHASAN}

Hubungan antara status gizi awal masuk rumah sakit terhadap lama rawat inap pasien lanjut usia berdasarkan metode MNA

Berdasarkan hasil penelitian, nilai RR pada hasil uji statistik bivariat dan multivariat menunjukkan

Tabel 4. Pengaruh hasil skrining dengan lama rawat inap

\begin{tabular}{|c|c|c|c|c|c|}
\hline \multirow{2}{*}{$\begin{array}{c}\text { Hasil } \\
\text { skrining }\end{array}$} & \multicolumn{2}{|c|}{ Lama rawat inap } & \multirow[b]{2}{*}{ Total } & \multirow[b]{2}{*}{$\mathbf{P}$} & \multirow{2}{*}{$\begin{array}{c}\text { RR } \\
(95 \% \mathrm{CI})\end{array}$} \\
\hline & $\begin{array}{c}\geq 7 \text { hari } \\
\text { n (\%) }\end{array}$ & $\begin{array}{c}<7 \text { hari } \\
\text { n (\%) }\end{array}$ & & & \\
\hline Kelompok berisiko & $\begin{array}{c}28 \\
(68,3)\end{array}$ & $\begin{array}{c}13 \\
(31,7)\end{array}$ & $\begin{array}{c}41 \\
(100)\end{array}$ & & \\
\hline Kelompok tidak berisiko & $\begin{array}{c}15 \\
(41,7)\end{array}$ & $\begin{array}{c}21 \\
(58,3)\end{array}$ & $\begin{array}{c}36 \\
(100)\end{array}$ & $0,02^{*}$ & $\begin{array}{c}1,63 \\
(1,05-2,54)\end{array}$ \\
\hline Total & 43 & 34 & 77 & & \\
\hline
\end{tabular}

*Signifikan $(p<0,05)$

Tabel 5. Pengaruh hasil skrining dengan status pulang

\begin{tabular}{|c|c|c|c|c|c|}
\hline \multirow{2}{*}{$\begin{array}{c}\text { Hasil } \\
\text { skrining }\end{array}$} & \multicolumn{2}{|c|}{ Status pulang } & \multirow[b]{2}{*}{ Total } & \multirow[b]{2}{*}{$\mathbf{P}$} & \multirow[b]{2}{*}{$\begin{array}{c}\text { RR } \\
(95 \% \mathrm{Cl})\end{array}$} \\
\hline & $\begin{array}{c}\text { Tidak sembuh } \\
\mathrm{n}(\%)\end{array}$ & $\begin{array}{c}\text { Sembuh } \\
\mathrm{n}(\%)\end{array}$ & & & \\
\hline Kelompok berisiko & $\begin{array}{c}31 \\
(75,6)\end{array}$ & $\begin{array}{c}10 \\
(24,4)\end{array}$ & $\begin{array}{c}41 \\
(100)\end{array}$ & & \\
\hline Kelompok tidak berisiko & $\begin{array}{c}21 \\
(58,3)\end{array}$ & $\begin{array}{c}15 \\
(41,7)\end{array}$ & $\begin{array}{c}36 \\
(100)\end{array}$ & 0,14 & $\begin{array}{c}1,29 \\
(0,93-1,79)\end{array}$ \\
\hline Total & 52 & 25 & 77 & & \\
\hline
\end{tabular}


Tabel 6. Analisis regresi logistik hasil skrining, usia, jenis penyakit, dan kelas perawatan

\begin{tabular}{|c|c|c|c|}
\hline Variabel & RR & $95 \% \mathrm{Cl}$ & $p$ \\
\hline \multicolumn{4}{|l|}{ Hasil skrining } \\
\hline Berisiko malnutrisi & 0,44 & $0,14-1,38$ & 0,16 \\
\hline Tidak berisiko & 1 & & \\
\hline \multicolumn{4}{|l|}{ Usia } \\
\hline$\geq 71$ tahun & 2,46 & $0,75-8,02$ & 0,05 \\
\hline $60-70$ tahun & 1 & & \\
\hline \multicolumn{4}{|l|}{ Jenis penyakit } \\
\hline Infeksi & 2,63 & $0,87-7,94$ & 0,08 \\
\hline Tidak infeksi & 1 & & \\
\hline \multicolumn{4}{|l|}{ Kelas perawatan } \\
\hline Kelas 2 dan 3 & 0,17 & $0,05-0,53$ & 0,00 \\
\hline Kelas 1 & 1 & & \\
\hline
\end{tabular}

Tabel 7. Analisis regresi logistik hasil skrining, jenis kelamin, riwayat hospitalisasi terhadap status pulang

\begin{tabular}{lccc}
\hline \multicolumn{1}{c}{ Variabel } & $\mathbf{R R}$ & $\mathbf{9 5 \%} \mathbf{C l}$ & $\mathbf{p}$ \\
\hline $\begin{array}{l}\text { Hasil skrining } \\
\text { Berisiko malnutrisi }\end{array}$ & 9,21 & $2,45-34,56$ & 0,00 \\
$\quad \begin{array}{l}\text { Tidak berisiko malnutrisi } \\
\text { Jenis kelamin } \\
\quad\end{array}$ & 1 & & \\
$\begin{array}{l}\text { Perempuan } \\
\text { Laki-laki }\end{array}$ & 0,22 & $0,06-0,85$ & 0,02 \\
$\begin{array}{l}\text { Riwayat hospitalisasi } \\
\text { Ya }\end{array}$ & 1 & & \\
$\quad$ & 2,54 & $0,76-8,50$ & 0,12 \\
$\quad$ Tidak & 1 & & \\
\hline & & &
\end{tabular}

hasil yang bertolak belakang. Pada hasil uji bivariat membuktikan bahwa kelompok berisiko malnutrisi mempunyai risiko lebih besar untuk mempunyai lama rawat inap yang lebih panjang dibandingkan dengan kelompok tidak berisiko malnutrisi. Sebaliknya, pada hasil uji multivariat menunjukkan bahwa kelompok tidak berisiko malnutrisi yang justru berisiko lebih besar untuk mempunyai rawat inap lebih panjang. Secara praktis dan klinis seharusnya ada konsistensi hasil bivariat dan multivariat. Adanya perbedaan ini karena pada analisis bivariat faktor pengganggu tidak dapat dikendalikan, sementara pada analisis multivariat faktor pengganggu dapat dikendalikan. Kelompok tidak berisiko malnutrisi mempunyai insiden penyakit kronis dan juga distribusi umur yang sebagian besar lebih tua dibandingkan dengan kelompok berisiko malnutrisi.

Penelitian di RSUP Dr. Sardjito tahun 2009 membuktikan bahwa perubahan asupan makan dan perubahan status gizi tidak berhubungan dengan lama rawat inap di rumah sakit (12). Berbeda dengan penelitian Braunschweig pada penelitiannya menghasilkan pasien rawat inap yang mengalami penurunan status gizi berhubungan dengan lama rawat inap, biaya rumah sakit yang lebih besar, serta frekuensi komplikasi yang lebih besar (13). Penilaian status gizi dapat dilakukan secara langsung maupun tidak langsung. Penilaian status gizi secara langsung berupa pengukuran antropometri, uji biokimia, penilaian klinis, dan uji biofisik sedangkan tidak langsung dengan tiga cara yaitu survei konsumsi makanan, statistik vital dan faktor ekologi (14). Tujuan penilaian status gizi akan dapat memberikan informasi awal untuk penyelenggaraan terapi gizi dan diet yang optimal pada pasien (15).

Senada dengan Depkes menyatakan bahwa beberapa faktor yang mempengaruhi status gizi lansia adalah: jenis kelamin, usia, gaya hidup, pendidikan, pekerjaan, status perkawinan, perumahan dan status ekonomi (16). Ketepatan dalam penilaian status gizi di rumah sakit merupakan hal yang penting karena penentuan status gizi yang tepat akan menghasilkan ketepatan dalam pemberian terapi gizi pada pasien (8). Hal ini senada dengan penelitian yang menyatakan bahwa prevalensi malnutrisi pada usia lanjut sangat tinggi (17). Malnutrisi terjadi paling tidak setengah dari pasien lansia di rumah sakit yang berhubungan dengan penyakit yang akut dan progresif. Hal ini senada dengan penelitian Sari bahwa usia lanjut merupakan kelompok yang rentan terhadap malnutrisi (10).

Pablo melakukan penelitian terhadap 60 pasien (18). Penilaian status gizi dilakukan dalam waktu 48 jam penerimaan, menggunakan indeks gizi yang berbeda subjective global assessment (SGA), nutrition risk index (NRI), gassul classification, instant nutritional assessment (INA), dan indeks gabungan. Sekitar $78,3 \%$ pasien yang ditemukan menjadi kurang gizi pada saat masuk rumah sakit. Malnutrisi tidak berhubungan dengan diagnosis, namun usia lansia berhubungan dengan prevalensi malnutrisi. INA adalah salah satu perangkat terbaik untuk mengidentifikasi pasien yang mengalami kekurangan gizi atau gizi 
buruk dan bermanfaat untuk memberikan gizi bagi yang membutuhkan.

Sementara itu, pada hasil penelitian ini didapatkan tidak ada hubungan yang bermakna antara status gizi awal dengan lama rawat inap pasien berdasarkan MNA. Artinya bahwa jika pasien lanjut usia memiliki risiko malnutrisi belum tentu karena lamanya rawat inap di rumah sakit, karena ada faktor lain yang dapat mempengaruhinya. Hal ini berbeda dengan hasil penelitian-penelitian yang telah dilakukan terhadap pasien di rumah sakit yang dilaporkan ada kaitan antara status gizi pasien dengan lama rawat inap $(19,8,20)$.

Semakin lama seseorang dirawat di rumah sakit, semakin akan berpengaruh pada kondisi fisiologisnya. Semakin lama dirawat, seseorang akan mengalami atropi otot karena kurang latihan. Atropi otot menyebabkan otot mengecil yang berarti menurun pula status gizi pasien, sehingga berpengaruh pada proses penyembuhan dan lama rawat. Berbeda dengan penelitian Braunschweig yang menemukan bahwa subjek yang status gizinya baik menjadi sedang, baik menjadi buruk, dan sedang menjadi buruk mempunyai rata-rata lama rawat inap berturut-turut 16, 23, dan 19 hari (vs 14 hari) (13).

\section{Hubungan status gizi awal masuk rumah sakit terhadap status pulang pasien lanjut usia berdasarkan metode MNA}

Menurut hasil analisis bivariat didapatkan bahwa tidak ada pengaruh antara hasil skrining terhadap status pulang. Sementara itu, diketahui bahwa ada pengaruh antara hasil skrining terhadap status pulang. Nilai RR pada hasil uji statistik bivariat dan multivariat menunjukkan hasil yang bertolak belakang yaitu pada hasil uji bivariat membuktikan bahwa kelompok tidak berisiko malnutrisi keluar dalam keadaan tidak sembuh lebih besar dibandingkan dengan kelompok berisiko malnutrisi, namun pada hasil uji multivariat menunjukkan bahwa kelompok berisiko malnutrisi yang justru pulang dalam keadaan sembuh. Secara praktis dan klinis, seharusnya ada konsistensi hasil bivariat dan multivariat. Adanya perbedaan ini karena pada bivariat ada beberapa faktor pengganggu yang tidak dapat dikendalikan. Ada beberapa subjek yang memiliki penyakit komplikasi seperti sepsis, anemia, strok, TB Paru, DM, aneroksia dan lain sebagainya.

Jenis kelamin dengan nilai $\operatorname{RR~} 0,22$ menunjukkan bahwa jenis kelamin bukan merupakan faktor risiko tetapi sebagai protektif. Hal ini karena jenis kelamin pasien tidak mempengaruhi status pulang. Dengan demikian, subjek perempuan memiliki risiko 0,22 kali lebih besar untuk pulang dalam keadaan tidak sembuh dibandingkan pulang dalam keadaan sembuh. Sementara itu, berdasarkan praktis dan klinis laki-laki memiliki risiko pulang dalam keadaan tidak sembuh. Ada hubungan yang bermakna antara usia dengan status pulang. Hal ini berbeda dengan penelitian Totoprajogo (21) yang dilaporkan bahwa status gizi kurang/buruk sangat mempengaruhi proses kesembuhan pasien dan meningkatkan komplikasi yang semuanya berakibat bertambah lamanya pasien dirawat, meningkatnya biaya perawatan, bertambah lamanya masa nonproduktif pasien serta bertambahnya risiko.

Pemberian nutrisi yang tidak adekuat mengakibatkan keadaan kurang gizi yang dapat meningkatkan morbiditas dan mortalitas (22). Sementara itu, Naber mengemukakan bahwa penurunan status gizi selama perawatan disebabkan oleh penyakit yang mendasari dan kekurangan intake makanan (23). Hubungan antara status gizi, penyakit yang mendasari, serta terjadinya komplikasi selama sakit merupakan hubungan yang timbal balik saling mempengaruhi satu sama lain dan digambarkan sebagai suatu bentuk segitiga.

Menurut Agustina, masalah kesehatan yang dihadapi lansia antara lain meningkatnya kerentanan terhadap penyakit infeksi dan noninfeksi dan disfungsi imunitas merupakan sebab utamanya (17). Namun demikian, pada penelitian ini tidak didapatkan hubungan yang bermakna antara status gizi awal pasien berdasarkan MNA dengan status pulang. Hal ini disebabkan ada faktor lain yang mempengaruhi.

Sementara itu, berdasarkan penelitian lain ditemukan bahwa pasien yang infeksi dan noninfeksi berisiko mengalami malnutrisi berturut-turut sebesar 
1,4 dan 1,5 kali (23). Hal ini berarti risiko pasien yang menderita penyakit noninfeksi lebih besar daripada yang menderita penyakit infeksi.

\section{KESIMPULAN DAN SARAN}

Ttidak ada pengaruh antara hasil skrining dengan lama rawat inap. Ada pengaruh antara usia, jenis penyakit dan kelas perawatan terhadap lama rawat inap. Ada pengaruh antara hasil skrining dengan status pulang dengan nilai RR 9,21. Demikian pula, ada pengaruh antara usia dan jenis kelamin dengan status pulang $(p<0,05)$. Sementara itu tidak ada pengaruh antara riwayat hospitalisasi dengan status pulang.

Bagi institusi rumah sakit, metode MNA dapat dimasukkan sebagai protap (prosedur tetap) pelayanan gizi pada kegiatan asuhan pelayanan gizi di ruang rawat inap pada pasien lanjut usia agar digunakan dalam menentukan kelompok berisiko malnutrisi dan tidak berisiko malnutrisi.

\section{RUJUKAN}

1. Depkes RI, Pedoman tatalaksana usia lanjut untuk tenaga kesehatan. Jakarta : Departemen Kesehatan RI; 2006.

2. Nadaek DC. Diagnosis Malnutrisi pada Lanjut Usia. Majalah GizMindo 2004;3(8):14-5.

3. Fischer FE. The dietitian in the hospital setting. In: Schneider HA, Anderson CE, Coursin DB, editors. Nutritional support of medical practice. Hargerstown: Medical Department Harper \& Row Publishers; 1977.

4. Budiningsari RD, Hadi H. Pengaruh perubahan status gizi pasien dewasa terhadap lama rawat inap dan biaya rumah sakit. Jurnal Gizi KInik Indonesia 2000; 1: 33-45.

5. Setiati, S. Terapi nutrisi pasien usia lanjut yang dirawat di rumah sakit. Dalam: Harjodisastro D, Syam AF, Sukrisman L, editors. Dukungan nutrisi pada kasus penyakit dalam. Jakarta: Pusat Penerbitan FKUI; 2006.

6. Hamid Y. Hak Pelayanan Kesehatan Lansia. Padang Ekspres, 2008.

7. Fatima N. Malnutrisi di rumah sakit. Majalah Gizi Medik Indonesia 2002;1(1):4-6.
8. Wyszynski DF, Crivelli A, Ezquerro S, Rodriguez A. Assessment of nutritional status in a population of recently hospitalized patients. Medicina (Buenos Aires) 1997;58: 51-7.

9. Gibson R. Principles of nutritional assessment. New York: Oxford University Press; 1990.

10. Sari NK. Deteksi dini malnutrisi usia lanjut. Dalam: Harjodisastro D, Syam AF, Sukrisman L, editors. Dukungan nutrisi pada kasus penyakit dalam. Jakarta: Pusat Penerbitan FKUI; 2006.

11. Kagansky N, Berrer $\mathrm{Y}$, Kore $\mathrm{Y}$, Parelman L, Knobler $\mathrm{H}$, Levy S. Poor nutritional habits are predictor of poor out come in very old hospitalized patients. Am JClin Nutr 2005; 82(4): 784-91.

12. Nurmala, Susetyawati, Budiningsari RD. Perubahan asupan zat gizi tidak berpengaruh terhadap lama rawat inap pada pasien dewasa di RSUP Dr. Sardjito Yogyakarta. Jurnal Gizi dan Dietetik Indonesia, 2014; 2(1): 14-22.

13. Braunschweig $C$, Gomez $S$, Sheean PM. Impact of declines in nutritional status on outcomes in adult patients hospitalized for more than 7 days. J Am Diet Assoc 2000; 100: 1316-22.

14. Jelliffe DB. The assesment of the nutritional status of the community. Geneva: WHO; 1966, p 10-96.

15. Hartono A. Terapi gizi \& diet rumah sakit. Jakarta: EGC; 2006.

16. Depkes RI. Pelayanan gizi rumah sakit. Jakarta: Departemen Kesehatan RI; 2005.

17. Agustina R, Ahmad Lukito W. Malnutrisi dan kaitannya dengan status imunitas lanjut usia. Majalah Gizmindo 2003; 2(6).

18. Pablo AMR, Izaga AM, Alday LA. Assessment of nutritional status on hospital admission: nutritional scores. Eur J Clin Nutr 2003;57: 824-31.

19. Robinson G, Goldstein M, Levine GM. Impact of nutritional status on drg length of stay. Journal of Parenteral and Enteral Nutrition 1987;11:4951.

20. Majid N. Status gizi awal pasien anak rawat inap RSUP Dr. Sardjito Sebagai Prediktor Lama Perawatan dan Status Pulang. Yogyakarta:Universitas Gadjah Mada; 2001. 
21. Totoprajogo OS. Prevalensi hospital induced malnutrition. Malang: Rumah Sakit Umum Daerah Dr.Saiful Anwar; 1994.

22. Soegih R. Pola penanganan 'kasus gizi' di puskesmas dan rumah sakit. Dalam: Daldiyono, Thaha AR, editors. Kapita Selekta Nutrisi Klinik. Jakarta:
Perhimpunan Nutrisi Enteral dan Parenteral Indonesia;1998, p 37-55.

23. Naber THJ, Schermer T, de Bree A, Nusteling $K$, Eggink L, Fruimel JW, Bakkeren J, Van Heereveld H, Katan M. Prevalence of malnutrition in nonsurgical hospitalized patients and its association with desease complication. Am J Clin Nutr 1997; 66: 1232-9. 